\title{
RUSSIA'S REAL SECTOR OF THE ECONOMY IN JANUARY-APRIL 2016: MAJOR FACTORS AND TRENDS
}

\author{
O.Izryadnova
}

According to preliminary data released by Rosstat, in Q1 2016, Russia's GDP constituted $98.8 \%$ (97.2\% a year earlier) against the corresponding period of the previous year. Downward trend in domestic consumption persists although the slump is losing its grip on the economy. Growth in agriculture and the extraction sectors remains unchanged. The chemical industry posts very high dynamics in the manufacturing sector. A low investment demand amid simultaneous contraction of consumer demand on engineering products hampers potential of its growth. The level of general unemployment in April 2016 came to $5.9 \%$ of economically active population with $5.6 \%$ at end of 2015. The burden of jobless on available vacancies is growing in the wake of gradual growth rates of unemployment.

The economic situation in January-April 2016 was determined by the trends, which were common in the last year. In the current year, domestic demand continues shrinking amid easing of external demand's positive effect on economic dynamic. In January-March 2016, for the first time over last ten quarters the foreign trade turnover of Russia was determined by a more profound contraction of exports (68.8\% on Q1 2015) against imports (84.8\% on the same period). As a result, the trade balance remained positive, its significant shrinkage was registered in absolute terms in current prices.

According to the preliminary data released by Rosstat, the volume index of GDP constituted $98.8 \%$ against the corresponding period of 2015. In Q1 2016 , changes in the structure of domestic market were determined by a more moderate than a year earlier pace of consumer and investment markets contraction, which peaked in $\mathrm{H} 22015$.

In April 2016, the consumer demand dynamics were characterized by a contraction of retail trade turnover by $4.8 \%$ and paid services rendered to the population by $0.8 \%$ in annual terms. During previous seven years, dynamic growth of income and consumption of the population was maintained by wage growth in public and private sectors of the economy, by growing demand for work force and as well as by increasing pensions, then in 2015-2016 slowdown of economic dynamics and tightening of social spending policy are threatening stability of these trends. In April 2016, real income of the population on a year-on-year basis constituted $92.9 \%$ due to a reduction of real wages to $98.3 \%$ of the indicator as of April 2015 following positive

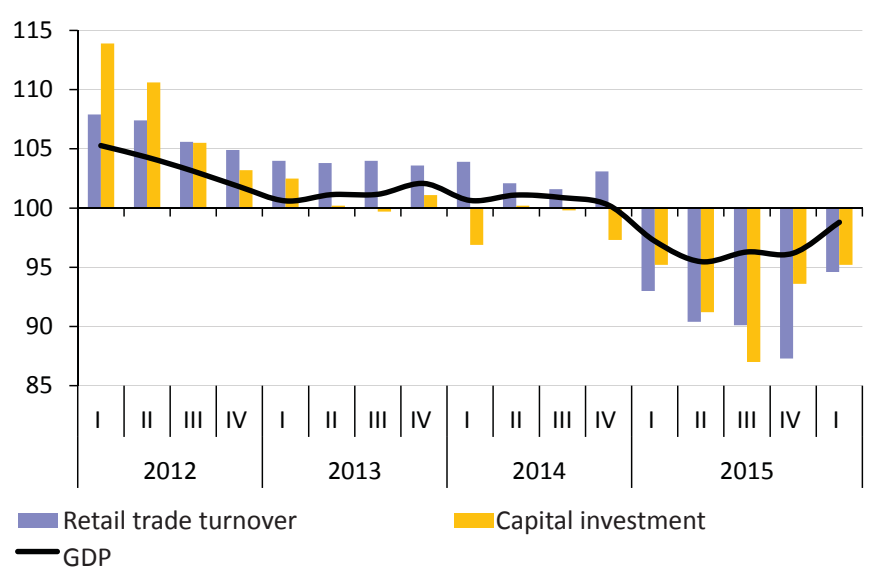

Source: Rosstat.

Fig. 1. Dynamics of GDP, turnover of retail trade and capital investment in 2012-2016, in \% to the previous year 
dynamics observed in February and March of the current year. On the whole in January-March 2016, the real wages contracted by $0.9 \%$ amid reduction by $9.2 \%$ during the same period of the previous year.

In the context of general downward trend in real money income of the population, there is a reduction in the drop of the consumer market and growth of structural shifts in the retail trade turnover towards growing share of the food market. In April 2016, the food products trade turnover down by $4.3 \%$ and non-food products - by $5.3 \%$ against April 2015.

The share of spending on foodstuffs increases in the structure of

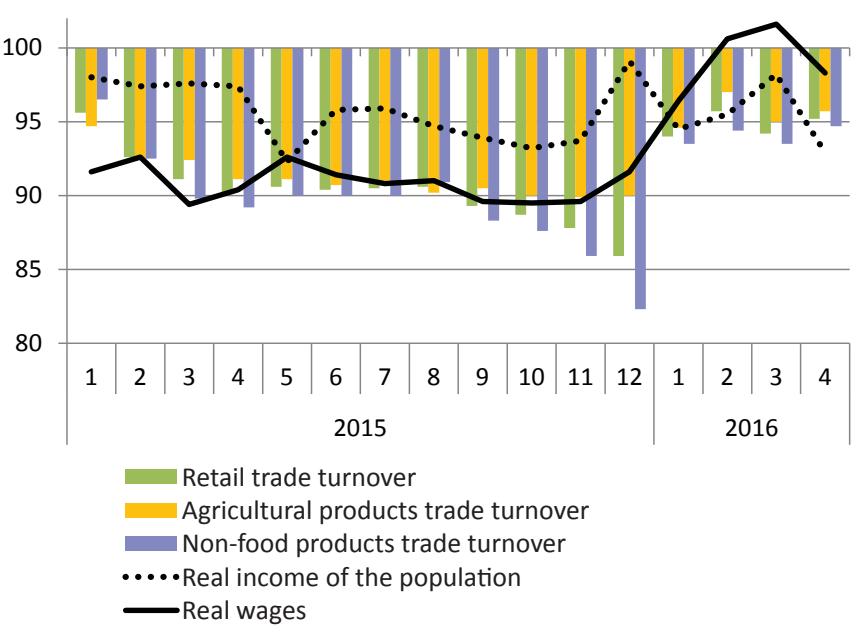

Source: Rosstat.

Fig. 2. Dynamics of the population's real income and retail trade turnover in 2015-2016, as \% to the corresponding period of the previous year income of the population, moreover this trend manifests itself among the low-income population. Despite the fact that the food products price index in April 2016 against December 2015 came to $102.7 \%$ ( $112 \%$ a year earlier) and that of non-food products $-102.9 \%$ (107.9\%), high level of accrued inflation and low dynamics of income remains a factor which restrains consumer activity of the population. Amid outstripping price growth on foodstuffs compared to the general inflation, socially vulnerable groups of population face growing risks, in particular, for the first time after 1999 crisis poverty rate grow was observed.

The situation in construction and investment complex is getting worse due to permanent shrinkage of activity since H2 2013. In the course of last three years, the low investment demand determines weak dynamics of development and reflects deep structural problems unfolding in the economy. In April 2016, the construction volume constituted $94.1 \%$ and commissioning of new housing came to $93.3 \%$ of the corresponding indicator of the previous year. The situation is getting worse due to a reduction of financing of the investment projects on the backdrop of general slowdown of the economy and retention of high interest rates. At the same time, uncertainty, sanctions and reduction of the investment activity of private investors negatively affect the investment demand. In Q1 2016, capital investment amounted to $95.2 \%$ of the last year indicator. It should be noted that in the current year the rate of reduction of construction and investment activity somewhat slowed down compared to January-March 2015, but differentiation along the types of fixed-capital assets increased. In January-April 2016, decrease of commissioning of new housing came to $14.3 \%$ with growth at $29.4 \%$ registered a year earlier. Reduction of commissioning of new housing on the whole is due to adjustment and is determined by exceptionally high 2015 base when the hike of housing construction was due a sharp increase of investment activity of the population being one of the tools of saving amid growing inflation.

With existing trend towards contraction of construction and investment activity, analysis of investment dynamic in capital assets shows that in Q1 2016 in North-Western and Urals federal districts there was a positive dynamics 
against the corresponding period of the previous year and in Central and Far-Eastern federal districts positive trends of last year remained.

Structural features of activity at macro regional level determine nature of investment activity to a considerable extent. Growth of agricultural production and promotion of agricultural import substitution goes together with the increment of investment in agriculture in the Central, Volga, Southern, and NorthCaucasus federal districts. In case of the territories with high rate of spending in the housing construction (for example, North-Caucasus federal district) reduction of the popula-

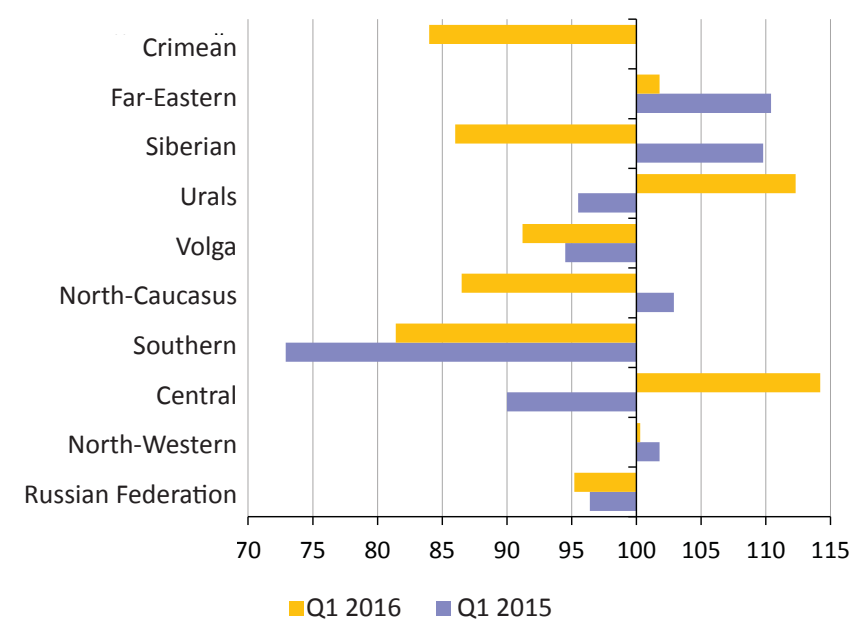

Source: Rosstat.

Fig. 3. Dynamics of investment in capital assets across federal districts in Q1 2015 and 2016, as \% to the corresponding period of the previous year tion's investment determined sharp contraction of the scale of construction works. Price increase on machinery and equipment together with a reduction of imports is a factor, which hampers the investment projects in regions with traditionally high rate of investment in machinery and equipment, for instance, in the Central, Volga, and Siberian federal districts. Price growth of construction and installation works affected the investment dynamic in the Northwestern, Southern, Urals, and Far-Eastern federal districts. Macro regions with high rate of direct foreign investment - the Central, Urals, Northwestern, and Far-Eastern federal districts - have overreacted at the shift in the terms of borrowing on world markets.

Against the background of restricted access to foreign money markets, issues related to the efficiency of use of revenues for increasing growth and productivity have become urgent. Reduction of the share of machinery and equipment in the investment pattern in capital assets due to a fall of domestic production and imports of capital goods, price growth of imported equipment and credit resources, and by nearly triple contraction of direct foreign investment hamper modernization and introduction of innovative technologies, which are paramount for increasing economic growth. According to estimates of the Ministry of Economic development, investment demand in 2016 will remain at the exceptionally low level. In this case, increased efficiency of territorial potential, industrial capacities, and mechanisms of diversification of investment activity according to a shift in domestic and foreign demand should be principal factor in maintaining production.

Contraction of domestic demand determined the dynamics of industrial production, which in January-April 2016 fell by $0.1 \%$ against the same period of last year, although in April 2016 it went up by 0.5\% against April 2015. The positive dynamics remain in extraction of mineral resources amid growing slump in the manufacturing industry. The volume of extraction of mineral resources in January-April 2016 moved up by 3.1\%, and in April - by 1.7\% against the same period of last year.

In April 2016 against April 2015, output in the manufacturing industry went up by $0.6 \%$ and during the period of January-April decreased by $1.8 \%$. 
The positive dynamics in January-April 2016 in annual terms was registered in the consumer and chemical complexes.

In April 2016, in annual terms foodstuffs production increased by $2.2 \%$, textiles and textile products manufacturing - by $3.7 \%$, leather production and leather products and footwear manufacturing - by $6.1 \%$, and household appliances - by $10.8 \%$. Consumer goods growth rate was registered in the majority of regions with high concentration of corresponding facilities - in the Central, Southern, and Volga federal districts. First positive effect generated by this trend both at the level of the subjects of the Federation and at the level of national economy should be taken into account: first, traditionally unstable character of development of these industries; second, difficulties related to provision with resources and materials for certain industries, in particular, for textile industry. In that respect, foreign policy conducted by the regional authorities aimed at the development of consumer complex industries together with support from small and medium-size businesses, which produce the major share of output in this complex especially in food and garment manufacture become urgent.

The output growth in the chemical industry in April 2016 in annual terms constituted $10.0 \%$ and output of rubber and plastic products $-8.5 \%$, which became the best indicator among manufacturing sector. Positive result, firstly, is due to the ruble's devaluation which allowed to increase supplies on the foreign market and simultaneously replace imports on the domestic one (pharmaceutical products, household chemicals, and production of plastics); secondly, commissioning of new plants and reaching project capacity in 2015 (production of polymers, and mineral fertilizers), and thirdly, upgrade of oil refineries and development of petrochemical production (in January-April 2016 oil refining depth came to $77.1 \%$ up 7.1 p.p. of the indicator a year earlier). Dynamic growth positively has affected the development character of macro regions with high concentration of chemical production - the Volga, Northwestern, Siberian, and Urals regions - and has allowed to ease the negative impact of production contraction in the metallurgical and machine building complexes.

Downward trend in the investment activity determined contraction of production of capital goods. Slump in the machine-building complex is rather significantly differentiated across types of activity. In January-April 2016, production of machinery and equipment went up by $4.4 \%$ amid the contraction of manufacture of means of transport and equipment by $4.2 \%$, and production of electrical equipment by $3.3 \%$ on the corresponding period of the previous year. Production growth of machinery and equipment was due to the growth of demand on the agricultural equipment, which supported positive dynamics of output in such macro regions as the Urals, Volga, Siberian, and Southern federal districts.

In January-April 2016, contraction of output of the automobile industry by $16.7 \%$ in comparison with the same period of the previous year negatively affected the dynamics of production of means of transport and equipment. This trend determined the development character in the regions of specialization - the Volga, Northwestern, Central, and Southern federal districts. Such dynamics is linked, on the one hand, with sharp shrinkage of demand, and on the other, with contraction and suspension of output of automobiles of foreign brands due to the price growth on imported components amid low local content in manufacturing. 
Table 1

\section{DYNAMICS OF INDUSTRIAL PRODUCTION ACROSS FEDERAL DISTRICTS OF THE RUSSIAN FEDERATION IN Q1 2015 AND 2016, AS \% TO THE CORRESPONDING PERIOD OF THE PREVIOUS YEAR}

\begin{tabular}{|c|c|c|c|c|c|c|}
\hline & \multicolumn{3}{|c|}{ Q1 2015} & \multicolumn{3}{|c|}{ Q1 2016} \\
\hline & 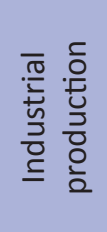 & 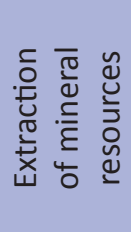 & 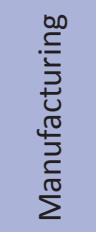 & 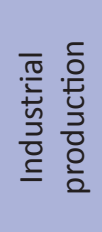 & 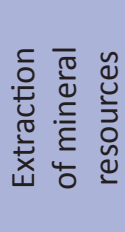 & 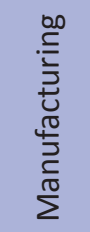 \\
\hline Russian Federation & 99.6 & 100.7 & 98.4 & 99.4 & 103.4 & 96.9 \\
\hline Central & 89.6 & 100.8 & 87.7 & 99.3 & 102.2 & 98 \\
\hline Northwestern & 99 & 106.4 & 96.1 & 100.2 & 104.2 & 96.6 \\
\hline Southern & 99.9 & 107.3 & 98.4 & 102 & 96.2 & 102 \\
\hline North-Caucasus & 97 & 97.5 & 97.9 & 108.2 & 92.3 & 117.1 \\
\hline Volga & 100.5 & 101.3 & 100.5 & 97.2 & 101.7 & 96.5 \\
\hline Urals & 100.6 & 99.4 & 104.3 & 103.8 & 103.6 & 104.5 \\
\hline Siberian & 99.1 & 103 & 95.2 & 99.2 & 102.5 & 101.9 \\
\hline Far-Eastern & 105.9 & 108.4 & 99.8 & 103.8 & 108.2 & 110.8 \\
\hline Crimean & 115 & 104.9 & 89.7 & 136.8 & 114.8 & 118.1 \\
\hline
\end{tabular}

Source: Rosstat.

The number of employed in April 2016 went up in comparison with January by $0.3 \%$. The number of unemployed (according to WLO methodology) in April 2016 on the corresponding period of the previous year moved up by $2.3 \%$ and constituted 4.5 million persons (5.9\% of economically active population); employment offices have registered 1.1 million of jobless citizens (1.3\% of economically active population). At the turn of 2016, downward trend in employment requirement increased amid growth of burden of unemployed on the available vacancies. Social and political stability will depend on the effectiveness of measures aimed at supporting socially vulnerable groups of population. Plan of actions developed by the Government of the Russian Federation is aimed at the ensuring stable socio-economic development of the Russian Federation in 2016 and comprises measures on social protection and state support in the sphere of employment and reduction of tension on the labor market ${ }^{1}$.

1 See in detail the situation on the labor market across regions: OMREO, № 8(26), 2016. 